Purdue University Purdue e-Pubs

$1-1-2003$

\title{
Outside Directors and Corporate Board Decisions
}

Jay Dahya

Baruch College

John J. McConnell

Purdue University

Follow this and additional works at: http://docs.lib.purdue.edu/ciberwp

Dahya, Jay and McConnell, John J., "Outside Directors and Corporate Board Decisions" (2003). Purdue CIBER Working Papers. Paper 26.

http://docs.lib.purdue.edu/ciberwp/26

This document has been made available through Purdue e-Pubs, a service of the Purdue University Libraries. Please contact epubs@purdue.edu for additional information. 


\title{
Outside Directors and Corporate Board Decisions
}

\author{
Jay Dahya \\ Baruch College, CUNY \\ Zicklin School of Business \\ One Bernard Baruch Way \\ Box B10-225 \\ New York, NY 10010 \\ (646) 312-3511 \\ jay_dahya@baruch.cuny.edu \\ John J. McConnell \\ Purdue University \\ Krannert School of Management \\ 403 W. State Street \\ West Lafayette, IN 47907-2056 \\ (765) 494-5910 \\ mcconnell@mgmt.purdue.edu
}

Current Draft: August 29, 2003

\begin{abstract}
Between 1993 and 2000 at least 18 countries saw publication of guidelines that propose minimum representation of outside directors on corporate boards. The apparent premise underlying this movement is that boards with significant outside directors will make different and, perhaps, better decisions than boards dominated by inside directors. As the first-mover in this movement, the U.K. provides a laboratory for a "natural experiment" to examine this presumption empirically. We investigate one important board task - - the appointment of the CEO - - to determine whether boards are more likely to appoint an outside CEO after they have increased the representation of outside directors to comply with the exogenously imposed standards. We find that the (coerced) increase in outside directors leads to an increase in the likelihood of an outside CEO appointment. Additionally, announcement period stock returns indicate that investors appear to view appointments of outside CEOs as good news. Apparently, boards with more outside directors make different (and perhaps better) decisions.
\end{abstract}

Correspondence: John J. McConnell, Purdue University, Krannert School of Management, 403 W. State Street, West Lafayette, IN 47907-2056. 


\section{Outside Directors and Corporate Board Decisions}

\section{Introduction}

Historically, the composition of the boards of directors of publicly-traded U.S. corporations has differed from that of most other countries in that U.S. boards have been characterized by substantial representation and, in most cases, a majority of outside directors. For example, in 1990, for 421 of the Fortune 500 firms (i.e., 84.2\% of the firms) outsiders comprised at least $50 \%$ of the board membership. In comparison, in 1990 , of the largest $25 \%$ of firms, ranked by market capitalization, listed on the stock exchanges of the U.K., France, Italy, Australia, South Africa, Hong Kong, Singapore, Malaysia, Thailand, India, Brazil and Mexico, outsiders comprised $50 \%$ or more of the board in less than $18 \%$ of the firms in each country.

Over the last decade and beyond, pressure has come to bear on publicly-traded corporations worldwide to increase representation of outside directors. Between 1993 and December 2000, at least 18 countries witnessed publication of reports sponsored by their governments and/or their major stock exchanges that advocated or mandated minimum standards for outside director representation on boards of publicly-traded companies. These minimum standards typically represent a major increase in outside board membership in these countries relative to the early 1990 s and before.

Arguably, the recent global movement toward a more prominent role for outside directors can be traced to the Cadbury Report issued in 1992 in the U.K. Among other things, the Cadbury Report recommended that publicly-traded U.K. companies have at least three outside directors. Compliance with the Cadbury recommendation represented a sea-change for U.K. companies. As documented by Dahya, McConnell and Travlos (DMT) (2001), during 1988, 
outsiders comprised a majority of the board for only 21 of the Financial Times (FT) 500 and, of all London Stock Exchange (LSE) companies, only $26.7 \%$ had at least three outside directors. In comparison, during 1998, outsiders were a majority of the board for 257 of the FT 500 firms, and $62.3 \%$ of all LSE listed companies had at least three outside directors.

The apparent premise underlying the movement towards greater outside director representation is that more outside directors will lead to different and, presumably, better decisions by the board. The purpose of this study is to examine one board task to determine whether this premise is justified. The task upon which we focus is the appointment of the top manager. Our motivation for focusing on the appointment of CEOs derives from the generally accepted proposition that one of the key responsibilities of corporate boards is the hiring of top managers. We ask whether the fraction of outside directors on the board is correlated with the decision of whether to hire an insider or outsider as the new CEO when the firm's current CEO is replaced. We use the U.K. as the laboratory for this study because, as we noted, the U.K. can be viewed as a first-mover in the global push toward the prescribed inclusion of outside directors.

Additionally, as we will document further below, prior to the mid-1990's, in terms of its board compositions, the U.K. was the inverse of the U.S., with outside directors being a distinct minority in the U.K. and a heavy majority in the U.S. Most importantly, however, because of its status as the first-mover, the U.K. provides a sufficiently long time series of data following its recent emphasis on the inclusion of outside board members to allow for a "before-and-after event" comparison.

The prior study most closely related to ours is Borokhovich, Parrino, and Trapani (BPT) (1996) who study board composition and CEO appointments in the U.S. They analyzed 969 CEO appointments over the interval 1970 through 1988. After controlling for other factors, they 
report a positive and significant correlation between the fraction of outside directors and the probability of a newly-appointed CEO being from outside the company. One of the questions we address here is whether that result is unique to the U.S. Additionally, however, we go beyond BPT in that their study potentially suffers from endogeneity in the CEO appointment process: In particular, it may be that companies that tend to appoint outside CEOs also tend to have a larger fraction of outside directors. Thus, the correlation reported by BPT may be spurious. Our study provides a way around this endogeneity.

Specifically, our study of CEO appointments in the U.K. spans the eleven years 1989 through 1999 and, thus, encompasses the period from before to after the publication of the Cadbury Report in 1992. Publication of the Report represents a "natural" experiment in which an exogenous force coerced companies into adding outside directors. If the appointments process is endogenous, then, presumably, addition of outside directors in response to this exogenous mandate will have no effect on the CEO appointment process. We do not find that to be the case.

Both before and after U.K. firms comply with the Cadbury Report, the probability of an outside CEO appointment increases with the fraction of outside board members. Additionally, however, once a firm comes into compliance with the Cadbury recommendation, the probability of an outside CEO appointment increases further. Thus, at least in part, the appointment decision is not endogenous: Outside directors tend to appoint outside CEOs.

As we describe later, different countries have taken different prescriptive routes toward increasing the role of outside directors. The U.K. and Thailand have specified a minimum number of outsiders. Australia, Belgium, Brazil, Greece, India, Mexico, and Singapore have specified a minimum fraction. France, Malaysia, and South Africa have specified both a 
minimum number and a minimum fraction. Korea has initially specified a minimum number of outside directors with a further provision that provides for a minimum fraction of outside directors over a longer term. We also address the question of whether it is the number or fraction of outside directors that affects the CEO appointment decision. We determine that the fraction of outside directors dominates the number, and that, after controlling for other factors in a multivariate analysis, the relationship between the fraction of outside directors and the company's propensity to appoint an outside CEO increases as the fraction of outside directors increases.

Of course, these results only indicate that more outsiders on the board lead to different decisions (or, at least, different CEO appointment decisions). The results do not indicate whether the CEO appointment decisions are better. To address that question, at least preliminarily, we conduct an event study in which we examine excess stock returns around announcements of CEO appointments. For the companies in our sample, announcements of outside CEO appointments are accompanied by an average 2-day excess stock return $(0.79 \%)$ that is significantly greater than the average 2-day excess stock return that accompanies inside CEO appointments $(0.20 \%)$. Thus, given that the probability of an outside CEO appointment increases as the fraction of outside directors increases, the global push toward a more prominent role for outside directors is apparently good news for shareholders. Not only are the board's decisions different, on average, investors apparently expect them to be better.

\section{The global movement toward outside directors}

As we noted, in 1992, the Report on the Financial Aspects of Corporate Governance issued by the Cadbury Committee recommended, among other things, that boards of publicly- 
traded U.K. companies include at least three outside directors. Although these recommendations have not been legislated, the committee was appointed by the government and the recommendations have been adopted by the LSE. Between publication of the Cadbury Report and December 2000, at least 18 other countries witnessed publication of similar reports. The introductory statement in the Handbook for Issuers on The Copenhagen Stock Exchange (2001) offers up a justification for this global movement:

Initially, the Corporate Governance debate arose partly in response to pressure from the increasingly prevalent institutional ownership, and partly in response to financial scandals at the end of the 1980's... The Cadbury Report contained a number of specific recommendations regarding good corporate governance also called 'best practice' or 'code of conduct'. The aim was to meet the demands of the institutional owners and to prevent new business and financial scandals... The debate has more recently moved from primarily being driven by a wish to stimulate 'owner activism' and increase the supervision of management... (p. 1)

In that spirit, in 1993, the Swedish Shareholders Association established guidelines for boards of publicly-traded Swedish corporations that closely mimicked those of the Cadbury committee. In 1994, the King Committee Report on Corporate Governance in South Africa recommended that publicly-traded companies have at least 2 outside directors and equal numbers of inside and outside directors and, in 1995, the Bosch Committee Report on Corporate Practices and Conduct in Australia prescribed that, for listed firms, a majority of the board be outsiders and at least one-third be independent.

In 1998, the Report on Desirable Corporate Governance issued by the Confederation of Indian Industry promulgated that for large firms at least 30\% of the board comprise outside directors unless the chairman of the board is also CEO, in which case the fraction of outsiders should be at least 50\%; the Report on the Roles, Duties and Responsibilities of the Directors of Listed Companies issued by the Stock Exchange of Thailand mandated that boards of exchangelisted firms have at least 2 outside directors; and the Report on Corporate Governance for 
Belgian Listed Companies adopted by the Brussels Stock Exchanges specified that the board consist of a majority of outsiders.

In 1999, at least six countries witnessed the issuance of mandates and/or guidelines for board composition: In Korea, the Code of Best Practice for Corporate Governance, backed by the Korean Stock Exchange, recommended that financial institutions and large public corporations have at least 3 outside directors and gradually increase the ratio of outsiders to greater than 50\%; in Malaysia, a Report on Corporate Governance issued by the High Level Finance Committee and, in France, the Vienot Report on the Boards of Directors of Listed Companies in France - - proposed that one-third of the board comprise independent outside directors with no fewer than 2 outsiders; in Mexico, the Code of Corporate Governance prepared for listed companies recommended that at least $20 \%$ of the board be outsiders; and, finally, in Greece, the Principles of Corporate Governance issued by the Capital Market Commission and, in Brazil, the Code of Best Practice of Corporate Governance issued by the IBGC, recommended that outsiders comprise at least $50 \%$ of the board.

\section{Prior studies}

As we noted, the prior study most directly related to ours is Borokhovich, Parrino and Trapani (BPT) (1996). They analyzed 969 CEO appointments at 588 large publicly-traded U.S. companies over the period 1970 through 1988. Of these 969 appointments, 187 were outsiders. After controlling for corporate performance, firm size, and CEO share ownership, they report a significant positive correlation between the fraction of outside directors and the likelihood that a new CEO will be appointed from outside the firm. The apparent conclusion is that adding 
outside directors increases the probability that the board will appoint a new CEO from outside the company.

However, as argued by Hermalin and Weisbach (1998), board composition (i.e., the split between inside and outside directors) and CEO appointments may be endogenous. If so, it could be that firms that are more likely to appoint outside CEOs are also more likely to appoint outside directors. If that is the case, the correlation observed by BPT may be spurious. If this correlation is spurious, i.e., the CEO selection decision is endogenous, changes in board composition should have no impact on CEO selection. Suppose, for example, that firm A optimally has few outside directors (say 20\% outsiders) and optimally chooses its CEO from an internal labor pool, while firm B optimally has many outside directors (say $80 \%$ outsiders) and optimally chooses an outside CEO. If the CEO selection process is endogenous, and if an external force coerces these firms to reverse their board compositions, and if the boards continue to act optimally in selecting their CEOs, firm A will continue to select its CEO internally and firm B will continue to select its CEO from an external labor pool.

Because the Cadbury Report spurred dramatic changes in the composition of U.K. boards, our analysis of U.K. data provides an opportunity to alleviate the problems that may arise from the possible endogeneity of board composition and CEO selection. If the correlation observed by BPT is spurious, we should find no shift in the likelihood that outside CEOs are appointed in the U.K. following the Cadbury Report. That is, the CEO selection process should be unaffected in firms that are coerced into adding outside directors. The fraction of outside directors might increase, but board decisions will be unchanged.

Of course, BPT is not the only study to analyze the relation between board structure and CEO appointments. As part of their study of corporate performance and CEO turnover in Japan, 
Kang and Shivdasani (1995) examine factors that influence the decision by Japanese companies to appoint an outside CEO. They examine 174 CEO turnover events over the period 1985 through 1990. Of these, 18 represent outside appointments. The authors report that an outside CEO appointment is significantly more likely when the company's prior performance has been poor and when stock ownership is concentrated among several large shareholders. They also report a positive correlation between the presence of one or more outside directors on the board and the probability of an outside CEO appointment. But, with p-values ranging from 0.12 to 0.19 in various regression specifications, the coefficient of this variable is not significant at traditionally acceptable levels. Of course, the sample is quite small.

\section{Sample and data sources}

We construct an initial sample of 914 companies by selecting every second entry from a comprehensive set of companies listed on the LSE as of December 1988. For each company, stock price and accounting data are taken from Datastream for the years 1985 through 1988. If such data are not available, the company is dropped from the sample. Ninety-nine companies were dropped because of insufficient stock price data; 115 were dropped due to insufficient accounting data. The resulting sample contains 700 companies. For each of these firms, for each year 1988 through 1999, we used the Corporate Register and/or annual filings maintained at Companies House to identify the top manager. We identified the top manager as the individual holding the title of chief executive officer (CEO) or, if no individual held the title of CEO, we identified the executive chairman as the top manager. Henceforth, we refer to the top manager as the $\mathrm{CEO}$. 
For each year 1988 through 1999, we also used the Corporate Register and/or annual filings to determine the age of the CEO, the size of the board, the number of outside directors, the total number of shares held by board members, and the total number of shares held by institutions. A director is considered an outsider if he/she is listed as a "non-executive" director, he/she is not related to the company's controlling family, and he/she was not employed by the company historically. Among other things, this procedure identified all changes (i.e., all turnover and, therefore, all appointments) in the top management position for each company.

We are interested in whether newly-appointed CEOs come from within or outside the company. To make that determination, for each instance in which we identified a turnover/appointment in the CEO position, we reviewed the company's prior-year board roster in the Corporate Register and/or the company's annual filings. If the new CEO was already a member of the board, we consider this to be an inside appointment. If not, we reviewed articles in the Extel Weekly News Summaries, the Financial Times, and Macarthy's News Information Service to confirm that the new CEO was from outside the company. In this way, we were able to identify (and confirm) every new CEO as either an inside or an outside appointment. For certain tests, we repeated this procedure to determine whether the departing $\mathrm{CEO}$ had been an insider or an outsider at the time of his appointment.

We are also interested in the circumstances under which the new CEO was hired. In particular, we are interested in whether the previous CEO departed his/her position involuntarily. We classify turnover in the CEO position as "forced" by examining articles in the Extel Weekly News Summaries, the Financial Times, and Macarthy's News Information Service. Turnover is labeled forced when: (1) a news article states that the executive was "fired"; (2) an article states that the executive "resigned"; or (3) an article indicates that the company was experiencing poor 
performance. In addition, for (2) and (3), the executive must be less than 60 years old and no other article can indicate that the executive took a position elsewhere or cite health or death as the reason for the executive's departure.

In later analyses, we are interested in firm size and performance. For these analyses, we take accounting and stock price data from Datastream. Our measure of firm size is the book value of assets. We use both accounting earnings and stock returns to measure performance. To measure stock price performance, we use industry- and size-adjusted stock returns (ISARs), where ISARs are calculated by subtracting the daily stock returns of an industry- and sizematched portfolio from the return of the sample company beginning 153 trading days prior to, and ending 3 days prior to, the announcement of the CEO appointment. To construct the industry- and size-matched portfolio, for each company in our sample, all other companies with the same Financial Times Industry Classification (FTIC) code are ranked from largest to smallest according to their equity market values. The companies are divided into four size portfolios. The differences between the return on the stock in our sample and the equal-weighted average return of the appropriate industry- and size-matched portfolio are calculated. The sum of these differences is the ISAR for that company.

As our measure of accounting performance, we use 3-year average industry-adjusted return on assets (IAROA). For each year, for each company in the sample, we calculate ROA as earnings before depreciation, interest and taxes (EBDIT) divided by beginning of the year total assets. Then, for each firm with the same FTIC as the sample firm, we calculate ROA in the same way. Next, for each year, for each FTIC group, we determine the median ROA. IAROA is calculated by subtracting the industry median ROA from the sample company's ROA for each of 
the three years prior to a CEO appointment. The average of these three IAROAs is our measure of accounting performance.

\section{Analysis}

\subsection{CEO appointments and board composition: A first look}

As a first-pass analysis, we examine the relationship between CEO appointments and board composition by stratifying the companies in our sample into deciles according to the fraction of their boards comprising outside directors. This stratification of the sample is displayed in Table 1.

The table gives the total number of CEO appointments, the number of outside CEO appointments, and the number of outside CEO appointments as a fraction of the total number of CEO appointments according to the fraction of the board composed of outside directors. The primary statistic of interest to us is the percentage of outside CEO appointments relative to total appointments. The table clearly demonstrates a positive correlation between the percentage of outside CEO appointments and the fraction of outside directors. The percentage of outside CEO appointments increases with the fraction of outside directors, at least up to $70 \%$ outside directors. In the range of 0.60 to 0.70 outside directors, the percentage of outside CEO appointments reaches a maximum of $49.3 \%$. After $70 \%$ outside directors, the percentage of outside CEO appointments drops off slightly.

Additionally, although $40 \%$ of the total number of CEO appointments in our sample occur in companies for which outside directors comprise less than 0.40 of the board, only $8.0 \%$ of outside CEO appointments occur in these firms. Thus, in U.K. companies in which inside directors dominate the board, appointment of an outside CEO is rare. 
For comparison, in Table 1, we present similar data for U.S. CEO appointments taken from BPT (1996). (Recall their sample encompasses 588 large public companies for the years 1970 through 1988.) For BPT, however, the number of observations for firms with boards comprising 0 to 0.40 outside directors is so few that they compress these deciles into a single category. Contrary to the U.K., for the U.S., the bulk of all CEO appointments occur in the deciles of companies in which outside directors comprise more than 0.70 of the board membership. That is, most of the companies in the U.S. sample have boards dominated by outside directors.

Like the U.K., in the U.S., appointment of outside CEOs is rare in companies with boards composed of fewer than 0.40 outside directors. Of course, in the U.S., few CEO appointments of any kind occur for boards with fewer than 0.40 outside directors because such companies are relatively rare. A further commonality between the two sets of data is the positive relationship between the propensity for firms to appoint outside CEOs and the fraction of outside directors - as the fraction of outside directors increases from decile to decile, the fraction of outside CEO appointments increases as well, except at the very upper end of the range for U.K. companies. As we document later, in a multivariate context, this apparent drop off in the propensity to appoint outside CEOs disappears.

Thus, on the basis of the data so far, the evidence on CEO appointments and board composition indicates that results from the U.S. can be generalized to at least one other country. As we emphasized above, however, this relationship could be spurious due to an endogenous relationship between CEO appointments and the fraction of outside directors. 


\subsection{U.K. board composition and CEO appointments through time}

As a possible way to circumvent the potential endogeneity between board composition and CEO appointments, we focus on an interval surrounding the publication of the Cadbury Report in December 1992. Publication of the Cadbury Report presents a natural experiment in which an external force pressured U.K. companies into increasing the number of outside directors. DMT (2001) report that board sizes increased, on average, by about 1.5 members (from 5.7 to 7.3 ) and that the fraction of outside directors increased by about $10 \%$ (from $35.3 \%$ to $46.0 \%$ ) over the four years following the Cadbury Report (1993-1996) in comparison with the prior four years (1989-1992). They further report a significant increase in the rate of CEO turnover from before to after publication of the Report, and this increase in CEO turnover is concentrated among firms that came into compliance with the recommendations of the Cadbury Committee.

Table 2 reports data on board composition and CEO turnover/appointments by year for our sample for the period 1989 through 1999. As shown in the table, the total number of CEO appointments over this period is 523. On an annual basis, the number of appointments is relatively stable through time. However, because the number of firms in the sample declines through time due to mergers, bankruptcies and other delistings, the rate of turnover/appointments increases through time, especially after 1992. Over the four years, 1989 through 1992, the average annual rate of CEO turnover/appointments is $7.3 \%$. Over the next seven years, the average annual rate is $10.1 \%$. Thus, consistent with DMT, the rate of CEO turnover and, therefore, the rate of CEO appointments increased significantly after 1992 (p-value for the difference $=0.08$. $)$ Similarly, the average board size increased by about 1.5 members after 1992 (from 6.0 to 7.5 ) and the fraction of outside directors increased from about $43 \%$ to $55 \%$. 
In terms of inside vs. outside CEO appointments, the table demonstrates several phenomena. First, in those companies that appoint outside CEOs, the fraction of outside directors is significantly higher than in those companies that appoint inside CEOs (i.e., $57 \%$ vs. 46\%). Second, both for companies that appoint outside CEOs and those that appoint inside CEOs, the fraction of outside directors increases significantly, and by about the same proportion, from before to after 1992. This result is consistent with CEO appointments and board composition being endogenous. That is, regardless of whether the companies were appointing outside or inside CEOs, the fraction of outside directors has increased through time. For example, by 1999, for those companies that appointed inside CEOs in that year, the fraction of outside directors $(0.50)$ was about the same as for those firms that appointed outside CEOs prior to 1992 (0.51). Thus, adding outside directors may not alter the CEO appointment decision. It may merely change the board composition.

Third, however, according to the last column of the table, the number of outside CEO appointments as a fraction of all CEO appointments did increase from before to after 1992. Of the total of 189 CEO appointments over the four years 1989 through 1992, 26\% were outsiders. In comparison, of the 334 CEO appointments over the period 1993 through 1999, 32\% were outsiders. The p-value for the difference in percentages of outside CEO appointments from before to after 1992 is 0.03 . This result is consistent with an exogenously imposed increase in outside directors increasing the likelihood of an outside CEO appointment.

According to BPT (1996), in the U.S., an outside CEO is significantly more likely to be appointed when the prior CEO was "forced" from office than when he/she departed "voluntarily." To examine whether this effect is present in our data, we replicate the analysis of Table 2 separately for the set of companies in which the CEO appointments followed "forced" 
turnover and for all others. We do not present these results in a table. Similar to DMT, the rate of CEO turnover increased from before to after 1992, and the increase was concentrated in the set of companies with forced turnover. That is, the rate of CEO turnover increased following the Cadbury Report and the increase is due to an increase in "forced" CEO turnover. Additionally, in those cases where CEO turnover is forced, the fraction of outside CEO appointments is significantly higher than when CEO turnover is voluntary ( $54 \%$ vs. $17 \%$, p-value $<0.01)$. In our subsequent multivariate analysis, we control for "forced" turnover.

\subsection{Adoption of the Cadbury recommendations, board composition, and CEO appointments}

Our analysis of the time series of CEO appointments in Table 2 indicates that the rate of outside appointments increased following publication of the Cadbury Report. If the Report did have an impact on CEO appointments, the effect should be most pronounced among those companies that adopted the Cadbury Committee's outside director provision. That is, the company increased the number of its outside directors to at least three. In panel A of Table 3, we present data on the composition of the boards and CEO appointments for these 296 companies. That is, of the 700 companies in the initial sample, 296 of them increased the number of outside directors to at least three during the period covered by our study.

As shown in the table, for these companies, the average board size increased from about 4.7 members as of 1989 to about 7.9 as of 1999 and the fraction of outside directors increased from approximately 0.35 to approximately 0.63 . Also, the annual rate of CEO turnover/appointments increased from $7.0 \%$ over the four years prior to the Cadbury Report to $12.9 \%$ over the following seven years. The p-value for this increase is 0.02 . Thus, for the set of companies that adopted the Cadbury recommendation, the rate of CEO turnover/appointments increased significantly from before to after 1992. 
To determine whether increasing the presence of outside directors increased the propensity of boards to appoint outside CEOs, we divide the number of outside CEO appointments by the total number of appointments before and after 1992 for these 169 companies. For the four years prior to 1992, the percentage of outside CEO appointments was 24.4\%. For the seven years after 1992, the percentage of outside appointments was $35.4 \%$. The $\mathrm{p}$-value for the increase was 0.02 .

For comparison, panel $\mathrm{B}$ of Table 3 shows the same data for the set of companies that were already in compliance with the Cadbury recommendation as of December 1988. For these companies, the board size increased from about 6.2 to about 7.9 from before to after 1992, but the fraction of outside directors remained nearly constant at 0.60 throughout the time period. In terms of CEO turnover, this rate is also constant from before to after 1992. For the years 1989 through 1992, the annual rate of CEO turnover/appointments was 9.3\%; for the years 1993 through 1999, it was also 9.3\%. Similarly, outside CEO appointments as a percentage of total CEO appointments was nearly constant from before to after 1992 for this set of companies. For the years, 1989 through 1992, the rate of outside CEO appointments was $30.0 \%$; for the next seven years the rate was $28.6 \%$. The p-value for this difference is 0.81 . The data in panels A and B support the hypothesis that outside directors tend to appoint outside CEOs and that increasing the representation of outside directors on the board increases the likelihood of an outside CEO appointment.

Because the companies in our sample did not all comply with the Cadbury recommendation in the same year, we examine CEO appointments according to the year in which the company increased the number of outside directors to at least three following December 1992, we refer to this as the year of Cadbury adoption. We examine board 
composition and CEO appointments for the four years prior to the year of adoption and for the four years following adoption. These data are displayed in panel $\mathrm{C}$ of Table 3. In this panel, $\mathrm{y}$ is the year of adoption. The data in this panel starkly demonstrate the effect of Cadbury adoption on board composition. Over the four years before adoption, on average, outside directors comprised about $45.8 \%$ of the board; over the four years after adoption and post-1992, on average, outside directors comprised approximately $61.9 \%$ of the board.

Of particular interest to us is the increase in the fraction of outside CEO appointments that accompanies the increase in outside directors. As shown in the last column of panel C, over the four years prior to Cadbury adoption, outside CEO appointments were $20.0 \%$ of all CEO appointments. Over the four years following Cadbury adoption, the fraction of outside CEO appointments more than doubled to $40.1 \%$ of all CEO appointments (p-value for the difference $<0.01$.) This result strongly points to the interpretation that outside board members are more likely to appoint outside CEOs, and that an increase in outside directors is likely to affect the CEO appointment decision.

\subsection{Multivariate analysis}

Other factors, in addition to board composition, are likely to affect the decision of whether to appoint an inside or outside CEO. For example, the company's prior performance, the company's size, and the concentration of share ownership might influence the board's decision. To control for these other factors, we conduct binomial probit regressions on our sample of 523 CEO appointments.

In each of our regressions, the dependent variable is an indicator to identify whether the CEO appointment was an outsider (1) or an insider (0). In the first regression, the independent variables are the company's prior performance measured with ISARs as described above, firm 
size measured as $\log$ of book assets, the number of directors as of the beginning of the year, the fraction of directors who are outsiders as of the beginning of the year, the fraction of shares owned by the board as of the beginning of the year, the fraction of shares owned by institutions as of the beginning of the year, an indicator variable to identify whether the appointment follows "forced" turnover (1) or not (0), an indicator variable to identify whether the firm is a financial institution (1) or not (0), and an indicator variable to identify whether the incumbent CEO was from outside (1) or inside (0) the company.

We include the company's prior performance because companies that are performing poorly may be more likely to appoint an outside CEO; we include size because large companies may have a larger internal labor pool and may, therefore, be more likely to appoint an inside CEO; we include board size and share ownership because these factors may directly or indirectly influence the CEO appointment decision; we include an indicator for forced turnover because our descriptive data indicate that an outside CEO is more likely to be appointed when his/her predecessor was forced from office; we include an indicator for financial institutions because a cursory examination of the data indicates that financial institutions, as a general rule, have a larger fraction of outside directors than firms in other industries, and we include an indicator for whether the predecessor to the newly-appointed CEO was himself an insider or outsider at the time of his appointment. We include the fraction of outside directors to determine whether the apparent positive correlation between the fraction of outside directors and the likelihood of appointing an outside CEO persists after controlling for other factors. Finally, we include the square of the fraction of outside directors because the descriptive data in Table 1 present the possibility that the relationship between the probability of an outside CEO appointment and the fraction of outside directors may decline above a certain level of outside directors. 
The results of this regression are presented in the first column of Table 4. According to this regression, poorly performing companies are more likely to appoint an outside CEO (p-value $=0.08$ ); companies in which the prior CEO was "forced" from office are more likely to appoint an outside CEO ( $\mathrm{p}$-value $<0.01$ ); and smaller companies are more likely to appoint outside CEOs $(p$-value $=0.02)$. The coefficient of the incumbent's origin is negative, albeit not significant at the 0.10 level - - its p-value is 0.17 . This hints that, after controlling for other factors, if the existing CEO is from inside the firm, the next CEO is slightly more likely to come from outside the firm and vice versa. None of the other control variables even begin to approach significance at any meaningful level (all p-values $>0.28$ ). In each of our subsequent regressions, the p-values of these control variables, along with that of the incumbent's origin, are essentially the same as those in the first regression. As a result, we will not comment further on these variables.

The variables of particular interest, for our purposes, are the fraction of outside directors and the fraction of outside directors squared. The coefficient of the fraction of outside directors is positive and significant ( $\mathrm{p}$-value $=0.05$ ). The coefficient of the square of the fraction of outside directors is mildly negative, but does not approach statistical significance (p-value $=$ $0.59)$.

To explore further the possibility of a nonlinear relationship between the likelihood of an outside CEO appointment and the fraction of outside directors, we estimate a piecewise linear regression with four segments: 0.0 to $0.299,0.300$ to $0.499,0.500$ to 0.799 , and 0.800 to 1.000 for the fraction of outside directors. The results of this regression are given in the second column of Table 4. According to this regression, after controlling for other factors in a multivariate context, the relationship between the fraction of outside directors and the probability of an 
outside CEO appointment is positive and statistically significant over each of the four line segments - - the likelihood of an outside CEO appointment increases over the entire range as the fraction of outside directors increases. Because the explanatory power of the regression with the piecewise specification for the fraction of outside directors is marginally higher than for the regression with the fraction of outside directors squared, we use this specification in subsequent analyses.

The estimated positive correlation between the fraction of outside directors and outside CEO appointments is consistent with BPT (1996) and with the proposition that outside directors are more likely to appoint outside CEOs. However, as we discussed above, this result is also consistent with a spurious correlation between CEO appointments and the fraction of outside directors that derives from an endogenous relationship between the CEO appointment decision and board composition.

Our third regression aims to control for the possible endogeneity between the fraction of outside directors and the likelihood of an outside CEO appointment. This regression includes all of the control variables from the second regression. Additionally, we include an indicator variable to identify firms that came into compliance with the Cadbury recommendation following December 1992. That is, we include an indicator variable for the set of companies that increased the number of outside directors to at least three over the interval January 1993 through 1999. For these companies, if a CEO appointment occurs after compliance with this provision of the Cadbury Report, the indicator variable is set equal to 1. For all other appointments, this variable is set to 0 .

For each appointment, we also include the fraction of outside directors. However, for companies that adopt the Cadbury recommendation (i.e., change their boards to come into 
compliance) following 1992, we keep the fraction of outside directors at its pre-adoption level. The question we are asking, then, is - - does coming into compliance with the Cadbury Report affect the CEO appointment decision after controlling for what the composition of the board would have been at its pre-adoption level? For all other appointments, we use the fraction of the board composed of outside directors. Furthermore, for CEO appointments by companies that came into compliance during the period studied, but for which an appointment preceded compliance, we use the fraction of outside directors on the board as of the CEO appointment date.

The results of this regression are given in the third column of Table 4. The coefficients for the fractions of outside directors continue to be positive and to have the same levels of significance as in the prior regression. Additionally, the coefficient of the Cadbury adoption indicator variable is positive and highly significant ( $p$-value $=0.01$ ). This result indicates that companies that alter their boards to become compliant with the Cadbury Report are significantly more likely to appoint an outside CEO than they would have been in the absence of this alteration to their boards. Importantly, this result is inconsistent with the hypothesis that the CEO appointment process and board composition are (completely) endogenous. That is, these data indicate that this exogenously induced modification to board composition has altered CEO appointment decisions in the U.K.

One further question that we investigate is whether the movement to three outside directors is consequential in itself or whether it is the implied increase in the fraction of outside directors that fundamentally affects the CEO appointment decision. To explore that question we estimate the final regression in Table 4. This regression is the same as the third regression except that, for each appointment, we use the fraction of outside directors at the time of CEO 
appointment regardless of whether the company adopted the Cadbury recommendation. And, we include the indicator variable to identify firms that adopted the recommendation post-1992.

As shown in the table, the significance levels for the fraction of outside directors are similar to those in the second regression, but the significance level of the Cadbury adoption indicator variable drops to 0.58 . This regression indicates that it is not the appointment of three outside directors that is critical, rather it is the increase in the fraction of outside directors that is consequential to the appointment decision. Or, to put it differently, the appointment of three outside directors is likely to have much less effect in a board with 15 members than in a board with five members.

\subsection{Accounting performance}

We also estimated each of the regressions in Table 4 with our measure of accounting performance, IAROA, (as described in Section 3) in place of stock price performance, ISAR. The levels of significance of the coefficients in these regressions are nearly identical to those in Table 4.

\subsection{A different type of endogeneity}

Our analysis has considered the possibility that the correlation between the fraction of outside directors and the likelihood of an outside CEO appointment is spurious due to an endogeneity in CEO appointment decisions and board composition. But, our results could be influenced by a different type of endogeneity. For example, suppose that a firm is performing poorly. Suppose, then, that a decision is made both to add outside directors and to appoint an outside CEO. In that case, the observed correlation between the addition of outside directors and the appointment of an outside CEO is spurious. It is not due to any cause and effect relation between the presence of outside directors and CEO appointments. Rather, it is due to concurrent 
decisions to add outside directors and to appoint an outside CEO neither of which were in response to Cadbury and both of which would have happened in the absence of Cadbury.

This type of spurious correlation is unlikely to explain our results. First, in conducting our analysis, we do not consider a CEO appointment to be post-Cadbury adoption unless the appointment occurred during the year following the calendar year in which the firm increased the number of outside directors to three or more. Thus, the two events are not concurrent by construction.

Still, however, it may be that the outside CEO appointments tend to occur with a short lag following a change in board composition. If so, outside CEO appointments would be clustered immediately after Cadbury adoption. To evaluate this possibility, we examine the time series of outside CEO appointments relative to the year in which a company adopted Cadbury. For the 57 outside CEO appointments that occurred in the 4 years immediately after the companies adopted Cadbury, 14 occurred during the first calendar year following the year of adoption, 13 occurred during the second calendar year after adoption, 15 occurred during the third year, and 15 occurred during the fourth year. Over these 4 years, the number of firms in the sample declines slightly, but the number of outside CEO appointments remains steady. Thus, post-adoption outside CEO appointments were not clustered shortly after the companies adopted Cadbury. Again, these data are not consistent with the concurrent appointment of outside directors and an outside CEO, both of which would have occurred in the absence of Cadbury.

\section{Stock prices and appointments of CEOs}

Our analyses of board composition and CEO appointments indicate that the mandating of additional outside directors to corporate boards is likely to lead to different board decisions, or at 
least different CEO appointment decisions. Whether these decisions will be better is another question. In this section, we present evidence on that question by performing an event study in which we examine stock returns around announcements of appointments of CEOs.

To conduct our event study, we use the market model procedure with market model parameters estimated using daily stock returns over the interval of 153 trading days prior to the announcement day through 3 days prior to the announcement day. We examine excess stock returns over the 2-day interval that encompasses the day on which the company issued its press release announcing a CEO appointment and the following day.

We conduct our event study of CEO appointments with the 523 appointments in our sample. Announcement dates are taken from Extel Weekly News Summaries. As shown in panel A of table 5, for the 156 outside CEO appointments, the two-day announcement period average excess stock return is $0.794 \%$ with a p-value of 0.01 . For the 367 inside CEO appointments, the average excess stock return is $0.203 \%$ with a p-value of 0.20 . The p-value for the difference between the two average excess returns is less than 0.01 . Thus, the stock price reaction to both inside and outside CEO appointments is positive, but the reaction to outside appointments is significantly greater than the reaction to inside CEO appointments, and the reaction to inside appointments is not significantly different from zero. Thus, to the extent that increasing the presence of outside directors increases the likelihood of outside CEO appointments, coerced changes in board composition that increase the fraction of outside directors appear to be good news for shareholders - - not only do such modifications give rise to different board decisions, the stock price data indicate that market participants view the decisions as better.

As a refinement of this test, we split the outside appointments into those that occurred pre-1992 and/or pre-Cadbury adoption (the pre-adoption set) and those that occurred post-1992 
and post-Cadbury adoption (the post-adoption set) and conduct an event study for the two groups separately. We conduct this analysis because our set of outside CEO appointments contains some that occurred prior to the Cadbury Report and some that occurred post-1992, but were not among companies that had recently complied with the Cadbury Report. Presumably, the CEO appointment decisions by these companies were not altered by the Cadbury recommendation. They would have occurred anyway. It is possible that the significant excess return associated with outside appointments is due to those that would have occurred regardless of the Cadbury Report. As shown in Table 5, the average two-day announcement period excess return for the pre-adoption set is $0.78 \%$; for the post-adoption set, it is $0.80 \%$. Thus, the positive excess return associated with outside CEO appointment is not confined to those that would have occurred regardless of Cadbury - - outside CEO appointments appear to be good news for shareholders.

We examine one other factor. We split the sample according to the origin of the departing CEO and the origin of the new CEO. That is, we split the sample into four sets - those in which the departing CEO and the new CEO were from inside the company (319 observations); those in which the departing CEO and the new CEO were from outside the company (29 observations); those in which the departing CEO was from outside while his replacement was from inside (48 observations) and the remainder set (127 observations). The stock price reactions are positive and significant for outside CEO appointments and insignificant for inside appointments regardless of the incumbent's origins.

One well-recognized shortcoming of simple event studies such as this one is that they do not control for investors' expectations. For example, it could be that inside appointments are well anticipated, whereas, outside appointments involve greater uncertainty. In that case, it could be that inside and outside appointments are viewed equally positively by market 
participants, but because inside appointments have been well anticipated, the observed stock price reaction to such appointments is muted. If we could control for market expectations, we would expect to see the greatest stock price reaction, either positive or negative, to appointments that run counter to expectations. That is, suppose market participants had been expecting an inside CEO appointment, but the company announces an outside appointment. Then, assuming that an outside appointment is good news, we would expect a larger and positive stock price reaction relative to the case in which investors had been expecting an outside appointment and an outside appointment was announced even though the outside appointment is still good news.

Now consider the opposite case. Suppose market participants had been expecting an outside appointment, but the firm announces an inside appointment. Again, assuming that an outside appointment is good news, the stock price response should be lower relative to the case in which investors had been expecting an inside appointment and an inside appointment was announced.

To calibrate market expectations, we use the final regression from Table 4 to estimate the likelihood of an outside CEO appointment for each appointment in our sample. For the sample of outside CEO appointments, we group the 2-day announcement period excess return into three mutually exclusive groups according to the probability of an outside CEO appointment implied from Table 4: (1) low probability - - 0.00 to 0.33 , (2) medium probability - - 0.34 and 0.66 ; and (3) high probability - - 0.67 to 1.00 . The event study results for the corresponding groups of CEO appointments are presented in the last column in panel B of Table 5. Outside CEO appointments are associated with statistically significant positive announcement period returns and, importantly, as the probability of an outside appointment declines, the announcement period excess return becomes larger. That is, the more unexpected the outside appointment is, the more 
positive is the stock price response. For example, when the probability of an outside appointment is 0.67 to 1.00 , the announcement period excess return is $0.43 \%$ ( $\mathrm{p}$-value $=0.05$ ); when the probability of an outside appointment is 0.00 to 0.33 , the announcement period excess return is $1.135 \%$ (p-value $<0.01$ ). As regards inside CEO appointments, in no category is the announcement period return significantly different from zero.

To further explore the relation between market expectations and announcement period returns, we regress the 2-day announcement period excess returns against the implied probability of an outside CEO appointment from Table 4. The results of the cross-sectional regressions are presented in the last column in panel $\mathrm{C}$ of Table 5. If outside $\mathrm{CEO}$ appointments are good news, or at least better news than an inside appointment, the coefficient of this cross sectional OLS regression should be negative - - as it is, with a p-value of 0.10 . Then, for the sample of inside appointments, we perform the same regression the results of which are given in the middle column of panel $\mathrm{C}$ of Table 5. Again, if outside appointments are good news or, more accurately, if they are less better news than inside appointments, the coefficient for inside CEO appointments will be negative - - which it is again, but, in this case, the p-value is only 0.29 . The regression results support our interpretation of the event study to mean that investors view outside CEO appointments as good news.

\section{Commentary and conclusions}

Over the last decade (and beyond), stock exchanges and governmental bodies have pushed publicly-traded companies to increase the number and fraction of outside directors on their boards. Specifically, over the period 1993 through 2000, at least 18 countries have seen publication of official reports that recommend or mandate either a minimum fraction or a 
minimum number of outside directors for public companies and this minimum is substantially higher than the historical norm in those countries. This movement toward an increased role for outside directors appears to rest on the twin presumptions that boards with more outside directors will make different decisions, and that those decisions will be better, than otherwise would have been the case. Both of these premises are largely untested.

In this study, we investigate whether an increase in outside directors is likely to influence one, arguably primary, board decision - - the appointment of the company's CEO. Our investigation of data from the U.K. over a time period that spans the publication of the Cadbury Report - - which radically altered U.K. board compositions - - provides a natural experiment to examine the effect of a change in board structure on board decisions. With a sample of 523 CEO appointments over the period 1989 through 1999, we find a significant positive correlation between the likelihood of an outside CEO appointment and the fraction of outside directors on the board. More importantly, we find that the likelihood of an outside CEO appointment is significantly higher among those firms that became compliant with the recommendations of the Cadbury Report. This result indicates that increasing the representation of outside directors on the board is likely to influence board decisions, at least as regards the appointment of inside or outside CEOs.

An equally important question is whether the decisions will be better. We provide evidence on that question by conducting an event study surrounding announcements of CEO appointments in our sample. The average two-day stock price reaction to announcements of outside CEO appointments is significantly greater than the average two-day stock price reaction to announcements of inside CEO appointments. Thus, to the extent that outside directors are 
more likely to appoint outside CEOs, investors appear to perceive that boards with substantial outside director representation make better decisions.

Our data appear to indicate that the global movement toward greater outside director representation will lead to different and, perhaps, better board decisions. Several caveats are in order. First, our study encompasses only one country. Whether our results can be generalized globally is an open question. As emphasized by LaPorta, Lopez-de-Salines, Shleifer and Vishny (1997, 1998) and Stulz and Williamson (2001), among others, corporate governance systems appear to differ systematically across countries and cultures. If so, generalizing results from one political or cultural regime to another may be hazardous. Although our results are buttressed by an earlier study from the U.S., the similar common law origins of the U.K. and the U.S. corporate governance systems must be considered when applying the results to other countries. As other countries gain experience with their own mandates for additional outside directors, their data will provide fertile grounds for further study of the questions examined herein.

Second, our analysis considers only one specific board task. Whether our results can be generalized to other board decisions is also an open question.

Finally, the results of our analysis of whether decisions by boards with more outside directors are better (as well as different) are suggestive, but still preliminary. In future work, we hope to extend our analysis of whether outside directors make better decisions to encompass other countries and other, more general, measures of corporate performance. 


\section{References}

Aktiespararna's Corporate Governance Policy, Guidelines for Better Control and Transparency for Stockholders in Stock Market Companies, Sveriges Aktiespararna's Ruksforbund, March 1993, http://www.ecgn.ulb.ac.be/ecgn/docs/codes/aktiespararna.pdf.

Borokhovich, K. A., R. Parrino, and T. Trapani, 1996, "Outside Directors and CEO Selection," Journal of Financial and Quantitative Analysis, 31, 337-355.

Bosch Report on Corporate Practices and Conduct, Working group representing Australian Institute of Company Directors, Australian Society of Certified Practicing Accountants, Business Council of Australia, Law Council of Australia, The Institute of Chartered Accountants in Australia \& The Securities Institute of Australia, December 1995, http://www.ecgn.org/ecgn/codesreference.htm\#Bosch\%20Report.

Brazilian Institute of Corporate Directors, Brazilian Code of Best Practices, preliminary proposal, April 1999, http://www.worldbank.org/html/fpd/privatesector/cg/codes.htm.

Brickley, J. A., J. L. Coles, and R. L. Terry, 1987, “The Takeover Market, Corporate Board Composition, and Ownership Structure: The Case of Banking," Journal of Law and Economics, 30, 161-180.

Byrd, J. W., and K. A. Hickman, 1992, "Do Outside Directors Monitor Managers? Evidence From Tender Offer Bids,” Journal of Financial Economics, 32, 195-221.

Cadbury Report of the Committee on the Financial Aspects of Corporate Governance, Gee Publications, December 1992, http://www.ecgn.org/ecgn/docs/codes/cadbury.pdf.

Capital Market Commission's Committee on Corporate Governance in Greece, Principles of Corporate Governance in Greece: Recommendations for Its Competitive Transformation, June 1999, http://www.ecgn.org/ecgn/docs/codes/greece-engl.pdf. 
Cardon Report of the Belgium Commission on Corporate Governance, Brussels Stock Exchange, June 1998, http://www.calpers-governance.org/principles/international/other.asp.

Consejo Coordinador Empresarial, Comité de mejores práticas corporativas (Mexico), Código de mejores práticas, June 1999, http://www.ecgn.org/ecgn/docs/codes/Mexico/codemx.html.

Core, J. E., R. W. Holthausen, and D. F. Larcker, 1999, “Corporate Governance, CEO Compensation, and Firm Performance," Journal of Financial Economics, 51, 371-406.

Cotter, J., A. Shivdasani, and M. Zenner, 1997, "Do Independent Directors Enhance Target Shareholder Wealth During Tender Offers?," Journal of Financial Economics, 43, 195218.

Coughlan, A. T., and R. M. Schmidt, 1985, "Executive Compensation, Management Turnover, and Firm Performance," Journal of Accounting and Economics, 7, 43-66.

Dahya, J., J. J. McConnell, and N. G. Travlos, 2002, "The Cadbury Committee, Corporate Performance, and Top Management Turnover," Journal of Finance, 57, 461-483.

Denis, D. J., and D. K. Denis, 1995, “Performance Changes Following Top Management Dismissals," Journal of Finance, 50, 1029-1057.

Draft Report of the Kumar Mangalam Committee on Corporate Governance, Confederation of Indian Industry Report on Desirable Corporate Governance - A Code, April 1998, http://www.ecgn.org/ecgn/docs/codes/india-corpgovern.html.

Gilson, S., 1989, "Management Turnover and Financial Distress," Journal of Financial Economics, 25, 241-262.

Hermalin, B., and M. Weisbach, 1998, "Endogenously Chosen Boards of Directors and Their Monitoring of the CEO," American Economic Review, 88, 96-118. 
High Level Finance Committee on Corporate Governance, Report

on Malaysian Corporate Governance, March 1999 , http://www.worldbank.org/html/fpd/privatesector/cg/codes.htm.

Handbook for Issuers on the Copenhagen Stock Exchange, Corporate Governance in Denmark, December 2001.

Huson, M., R. Parrino, and L. T. Starks, 1998, "Internal Monitoring Mechanisms and CEO Turnover: A Long Term Perspective," working paper, University of Alberta, Edmonton, $\mathrm{AB}$.

Kang, J., and A. Shivdasani, 1995, "Firm Performance, Corporate Governance, and Top Executive Turnover in Japan," Journal of Financial Economics, 38, 29-58.

Kaplan, S. N., and D. Reishaus, 1990, "Outside Directorships and Corporate Performance," Journal of Financial Economics, 27, 389-410.

King Report on Corporate Governance, The Institute of Directors in Southern Africa, November 1994, http://www.worldbank.org/html/fpd/privatesector/cg/docs/king.pdf

Klein, A., and J. Rosenfeld, 1988, “Targeted Share Repurchases and Top Management Changes," Journal of Financial Economics, 20, 493-506.

Korean Commission on Corporate Governance (non-government body), Code of Best Practice for Corporate Governance, September 1999, http://www.ecgi.org/codes/country_documents/korea/code_korea.pdf.

La Porta, R., F. Lopez-de-Silanes, A. Shleifer, and R. W. Vishny, 1997, "Legal Determinants of External Finance," Journal of Finance, 52, 1131-1150.

La Porta, R., F. Lopez-de-Silanes, A. Shleifer, and R. W. Vishny, 1998, "Law and Finance," Journal of Political Economy, 106, 471-518. 
Lee, C. I., S. Rosenstein, N. Rangan, and W. N. Davidson III, 1992, "Board Composition and Shareholder Wealth: The Case of Management Buyouts," Financial Management, 21, 5872.

Martin, K., and J. J. McConnell, 1991, "Corporate Performance, Corporate Takeovers, and Top Management Turnover," Journal of Finance, 46, 671-687.

Murphy, K. J., and J. L. Zimmerman, 1993, "Financial Performance Surrounding CEO Turnover," Journal of Accounting and Economics, 16, 273-315.

Parrino, R., 1997, "CEO Turnover and Outside Succession: A Cross-Sectional Analysis," Journal of Financial Economics, 46, 165-197.

Shivdasani, A., 1993 "Board Composition, Ownership Structure, and Hostile Takeovers," Journal of Accounting and Economics, 16, 167-198.

Stock Exchange of Thailand, The Roles, Duties and Responsibilities of the Directors of Listed Companies, October 1998, http://www.set.or.th/th/index.html.

Stulz, R. M., and R. Williamson, 2001, "Culture, Openness, and Finance," working paper, Ohio State University, Columbus, $\mathrm{OH}$.

Vienot II report on the boards of directors of listed companies in France, Mouvement des Enterprises de France (MEDEF) and Association Francaise des Enterprises Privees (AFEF), July 1999, http://www.ecgi.org/codes/country_documents/france/vienot2_en.pdf.

Wahal, S., K. W. Wiles, and M. Zenner, 1995, "Who Opts Out of Antitakeover Protection? The Case of Pennsylvanian's SB 1310," Financial Management, 24, 22-39.

Warner, J. B., R. L. Watts, and K. H. Wruck, 1988, "Stock Prices and Top Management Changes," Journal of Financial Economics, 20, 461-492. 
Weisbach, M., 1988, "Outside Directors and CEO Turnover," Journal of Financial Economics, 20, 431-460.

Yermack, D., 1997, "Good Timing: CEO Stock Option Awards and Company News Announcements," Journal of Financial Economics, 52, 449-476. 
Table 1

CEO appointments classified according to composition of the board of directors for a sample of 700 U.K. companies over the period 1989 through 1999 in comparison with CEO appointments for a sample of 969 U.S. companies over the period 1977 through 1988

\begin{tabular}{|c|c|c|c|}
\hline $\begin{array}{l}\text { Fraction } \\
\text { of outside } \\
\text { directors }\end{array}$ & $\begin{array}{l}\text { CEO } \\
\text { turnover \& } \\
\text { appointments }\end{array}$ & $\begin{array}{l}\text { Outside } \\
\text { CEO } \\
\text { appointments }\end{array}$ & $\begin{array}{l}\text { Outside CEO } \\
\text { appointments as } \\
\text { percent of all } \\
\text { CEO appointments }\end{array}$ \\
\hline
\end{tabular}

Turnover and appointments for U.K. companies

\begin{tabular}{rrrl}
\hline $0-0.09$ & 59 & 1 & $1.70 \%$ \\
$\geq 0.10-0.19$ & 40 & 1 & 2.50 \\
$\geq 0.20-0.29$ & 57 & 4 & 7.02 \\
$\geq 0.30-0.39$ & 53 & 7 & 13.21 \\
$\geq 0.40-0.49$ & 48 & 18 & 37.50 \\
$\geq 0.50-0.59$ & 94 & 46 & 48.94 \\
$\geq 0.60-0.69$ & 73 & 36 & 49.32 \\
$\geq 0.70-0.79$ & 29 & 13 & 44.83 \\
$\geq 0.80-0.89$ & 48 & 20 & 41.68 \\
$\geq 0.90-1.00$ & 22 & 10 & $45.45 \%$
\end{tabular}

Total

523

156

\begin{tabular}{|c|c|c|c|}
\hline $\begin{array}{l}\text { Fraction } \\
\text { of outside } \\
\text { directors }\end{array}$ & $\begin{array}{l}\text { CEO } \\
\text { turnover \& } \\
\text { annointments }\end{array}$ & $\begin{array}{l}\text { Outside } \\
\text { CEO } \\
\text { annointments }\end{array}$ & $\begin{array}{l}\text { Outside CEO } \\
\text { appointments as } \\
\text { percent of all } \\
\text { CEO anpointments }\end{array}$ \\
\hline
\end{tabular}

Turnover and appointments for U.S. companies

$\begin{array}{rrrl}0-0.40 & 35 & 2 & 5.71 \% \\ \geq 0.40-0.50 & 54 & 7 & 12.96 \\ \geq 0.50-0.60 & 109 & 16 & 14.68 \\ \geq 0.60-0.70 & 198 & 35 & 17.68 \\ \geq 0.70-0.80 & 253 & 49 & 19.37 \\ \geq 0.80-0.90 & 261 & 61 & 23.37 \\ \geq 0.90-1.00 & 59 & 17 & 28.81 \%\end{array}$

Total

969

187

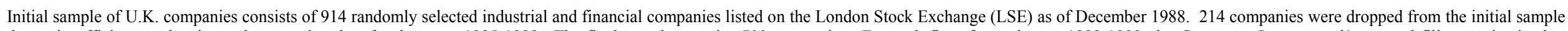

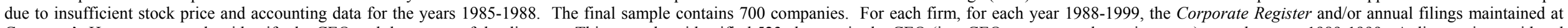

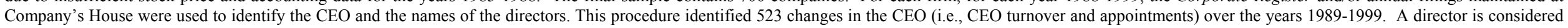

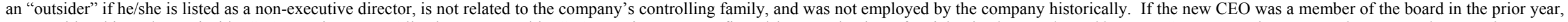

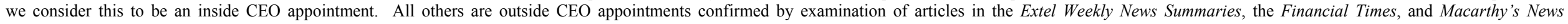
Information Service. Data for a sample of 969 CEO changes (i.e., CEO turnover and appointments) at 588 large U.S. firms for the years 1970-1988 are from Borokhovich, Parrino and Trapani (1996). 
Table 2

Number and rate of inside and outside CEO appointments over the period 1989 through 1999 for a sample of 700 U.K. companies

\begin{tabular}{|c|c|c|c|c|c|c|c|c|c|c|}
\hline \multicolumn{6}{|c|}{ All firms } & \multicolumn{2}{|c|}{$\begin{array}{c}\text { Inside } \\
\text { CEO appointments }\end{array}$} & \multicolumn{3}{|c|}{$\begin{array}{c}\text { Outside } \\
\text { CEO appointments }\end{array}$} \\
\hline Year & $\begin{array}{l}\text { Number of } \\
\text { firms at } \\
\text { beginning } \\
\text { of the year }\end{array}$ & $\begin{array}{l}\text { CEO } \\
\text { turnover \& } \\
\text { appointments }\end{array}$ & $\begin{array}{l}\text { Rate of CEO } \\
\text { turnover \& } \\
\text { appointments }\end{array}$ & $\begin{array}{l}\text { Board } \\
\text { size }\end{array}$ & $\begin{array}{l}\text { Average } \\
\text { fraction } \\
\text { of } \\
\text { outside } \\
\text { directors } \\
\end{array}$ & Number & $\begin{array}{l}\text { Average } \\
\text { fraction } \\
\text { of } \\
\text { outside } \\
\text { directors } \\
\end{array}$ & Number & $\begin{array}{l}\text { Average } \\
\text { fraction } \\
\text { of } \\
\text { outside } \\
\text { directors } \\
\end{array}$ & $\begin{array}{l}\text { Outside CEO } \\
\text { appointments } \\
\text { as percent of } \\
\text { all CEO } \\
\text { appointments }\end{array}$ \\
\hline 1989 & 700 & 49 & 7.0 & 5.9 & 0.35 & 36 & 0.32 & 13 & 0.43 & $26.53 \%$ \\
\hline 1990 & 662 & 48 & 7.3 & 6.6 & 0.42 & 36 & 0.38 & 12 & 0.55 & 25.00 \\
\hline 1991 & 626 & 47 & 7.5 & 5.6 & 0.44 & 34 & 0.42 & 13 & 0.50 & 27.66 \\
\hline 1992 & 601 & 45 & 7.5 & 6.0 & 0.49 & 34 & 0.47 & 11 & 0.56 & 24.44 \\
\hline 1993 & 578 & 48 & 8.3 & 7.3 & 0.55 & 34 & 0.49 & 14 & 0.57 & 29.17 \\
\hline 1994 & 539 & 47 & 8.7 & 7.2 & 0.50 & 32 & 0.45 & 15 & 0.53 & 31.91 \\
\hline 1995 & 499 & 48 & 9.6 & 7.6 & 0.50 & 34 & 0.48 & 14 & 0.54 & 29.17 \\
\hline 1996 & 477 & 51 & 10.7 & 7.6 & 0.53 & 36 & 0.46 & 15 & 0.63 & 29.41 \\
\hline 1997 & 458 & 48 & 10.5 & 8.0 & 0.57 & 32 & 0.49 & 16 & 0.60 & 33.33 \\
\hline 1998 & 438 & 46 & 10.5 & 7.4 & 0.60 & 30 & 0.49 & 16 & 0.66 & 34.78 \\
\hline 1999 & 417 & 46 & 11.0 & 7.7 & 0.61 & 29 & 0.50 & 17 & 0.69 & $39.16 \%$ \\
\hline $\begin{array}{l}\text { Total } \\
\text { (Average) }\end{array}$ & & 523 & & & & 367 & $(0.46)$ & 156 & $(0.57)$ & \\
\hline
\end{tabular}

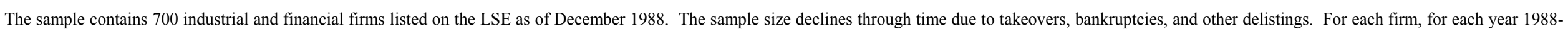

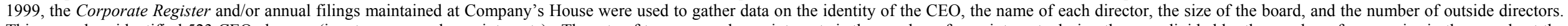

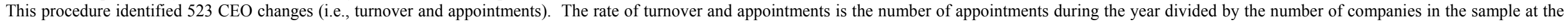

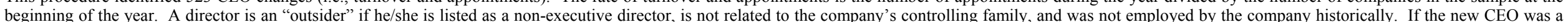

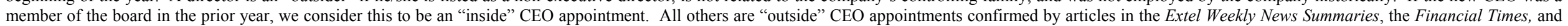
Macarthy's News Information Service. Average fraction of outside directors is the average of the number of outside directors divided by total directors for each company as of the beginning of each year. 
Table 3

Number and rate of inside and outside CEO appointments grouped by Cadbury Committee compliance with respect to a minimum of 3 outside directors over the period 1989 through 1999 for a sample of 700 U.K. companies

Panel A : CEO appointments for firms that adopted the Cadbury Committee recommendations of at least 3 outside directors anytime over 1989 through 1999

\begin{tabular}{|c|c|c|c|c|c|c|c|c|c|c|}
\hline \multicolumn{6}{|c|}{ All firms } & \multicolumn{2}{|c|}{$\begin{array}{c}\text { Inside } \\
\text { CEO appointments }\end{array}$} & \multicolumn{3}{|c|}{$\begin{array}{c}\text { Outside } \\
\text { CEO appointments }\end{array}$} \\
\hline Year & $\begin{array}{l}\text { Number of } \\
\text { firms at } \\
\text { beginning } \\
\text { of the year }\end{array}$ & $\begin{array}{l}\text { CEO } \\
\text { turnover \& } \\
\text { appointments }\end{array}$ & $\begin{array}{l}\text { Rate of CEO } \\
\text { turnover \& } \\
\text { appointments }\end{array}$ & $\begin{array}{c}\text { Board } \\
\text { size }\end{array}$ & $\begin{array}{l}\text { Average } \\
\text { fraction of } \\
\text { outside } \\
\text { directors }\end{array}$ & Number & $\begin{array}{l}\text { Average } \\
\text { fraction of } \\
\text { outside } \\
\text { directors }\end{array}$ & Number & $\begin{array}{l}\text { Average } \\
\text { fraction of } \\
\text { outside } \\
\text { directors }\end{array}$ & $\begin{array}{l}\text { Outside CEO } \\
\text { appointments } \\
\text { as percent of } \\
\text { all CEO } \\
\text { appointments }\end{array}$ \\
\hline 1990 & 277 & 18 & 6.5 & 4.7 & 0.30 & 14 & 0.26 & 4 & 0.44 & 22.22 \\
\hline 1991 & 271 & 20 & 7.4 & 4.9 & 0.37 & 15 & 0.30 & 5 & 0.47 & 25.00 \\
\hline 1992 & 264 & 21 & 8.0 & 5.0 & 0.41 & 16 & 0.36 & 5 & 0.49 & 23.81 \\
\hline 1993 & 250 & 25 & 10.0 & 6.3 & 0.57 & 17 & 0.51 & 8 & 0.64 & 32.00 \\
\hline 1994 & 243 & 27 & 11.1 & 7.0 & 0.62 & 17 & 0.55 & 10 & 0.68 & 39.04 \\
\hline 1995 & 233 & 26 & 11.2 & 7.5 & 0.61 & 17 & 0.56 & 9 & 0.67 & 34.62 \\
\hline 1996 & 224 & 31 & 13.8 & 7.8 & 0.64 & 20 & 0.57 & 11 & 0.68 & 35.48 \\
\hline 1997 & 222 & 32 & 14.4 & 8.2 & 0.65 & 20 & 0.53 & 12 & 0.69 & 37.50 \\
\hline 1999 & 208 & 31 & 14.9 & 7.9 & 0.63 & 20 & 0.55 & 11 & 0.67 & $35.48 \%$ \\
\hline verage) & & 284 & & & & 192 & $(0.53)$ & 92 & $(0.63)$ & \\
\hline
\end{tabular}

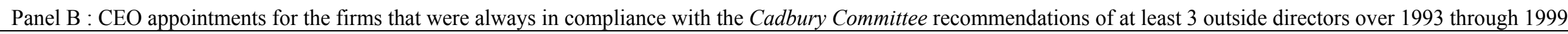

\begin{tabular}{|c|c|c|c|c|c|c|c|c|c|c|}
\hline 1989 & 203 & 17 & 8.4 & 6.3 & 0.59 & 12 & 0.43 & 5 & 0.62 & $29.41 \%$ \\
\hline 1990 & 194 & 18 & 9.3 & 6.2 & 0.64 & 12 & 0.47 & 6 & 0.60 & 33.33 \\
\hline 1991 & 184 & 19 & 10.3 & 6.2 & 0.56 & 13 & 0.51 & 6 & 0.70 & 31.58 \\
\hline 1992 & 170 & 16 & 9.4 & 6.0 & 0.59 & 12 & 0.51 & 4 & 0.62 & 25.00 \\
\hline 1993 & 159 & 16 & 10.1 & 6.8 & 0.62 & 12 & 0.54 & 4 & 0.68 & 25.00 \\
\hline
\end{tabular}




\section{Continued/ Table 3}

$\begin{array}{lrrrrr}1994 & 147 & 14 & 9.5 & 7.2 & 0.56 \\ 1995 & 138 & 14 & 10.1 & 7.9 & 0.65 \\ 1996 & 130 & 13 & 10.0 & 7.9 & 0.55 \\ 1997 & 119 & 9 & 7.6 & 7.9 & 0.61 \\ 1998 & 109 & 9 & 8.3 & 7.9 & 0.63 \\ 1999 & 105 & 9 & 8.6 & 7.9 & 0.61\end{array}$

Total

154

(Average)

Panel C : CEO appointments for firms that adopted the Cadbury Committee recommendations of at least 3 outside directors anytime over 1993 through 1999 centered around the year of adoption (y)

\begin{tabular}{|c|c|c|c|c|c|c|c|c|c|c|}
\hline$y-4$ & 235 & 18 & 7.7 & 5.0 & 0.40 & 15 & 0.34 & 3 & 0.48 & $16.67 \%$ \\
\hline$y-3$ & 239 & 19 & 8.0 & 5.7 & 0.45 & 15 & 0.36 & 4 & 0.50 & 21.05 \\
\hline$y-2$ & 244 & 20 & 8.2 & 6.1 & 0.47 & 16 & 0.34 & 4 & 0.53 & 20.00 \\
\hline$y-1$ & 248 & 23 & 9.3 & 6.4 & 0.48 & 18 & 0.40 & 5 & 0.55 & 21.74 \\
\hline \multicolumn{11}{|l|}{$\mathrm{y}$} \\
\hline$y+1$ & 247 & 39 & 15.8 & 7.8 & 0.61 & 25 & 0.56 & 14 & 0.69 & 35.90 \\
\hline$y+2$ & 242 & 33 & 13.6 & 7.7 & 0.63 & 20 & 0.59 & 13 & 0.68 & 39.39 \\
\hline$y+3$ & 237 & 36 & 15.2 & 7.8 & 0.62 & 21 & 0.58 & 15 & 0.64 & 41.67 \\
\hline$y+4$ & 233 & 34 & 14.6 & 8.0 & 0.60 & 19 & 0.55 & 15 & 0.65 & $44.12 \%$ \\
\hline & & 222 & & & & 149 & & 73 & & \\
\hline erage) & & & & & & & $(0.50)$ & & $(0.63)$ & \\
\hline
\end{tabular}

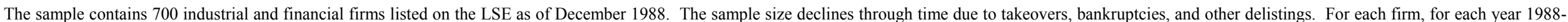

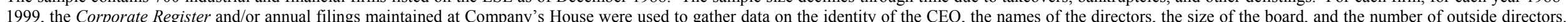

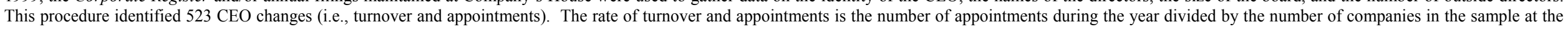

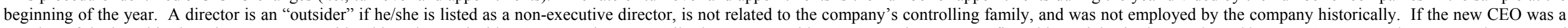

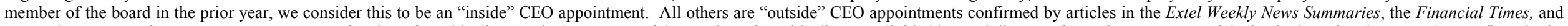

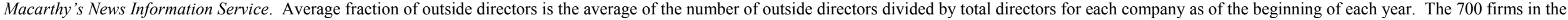

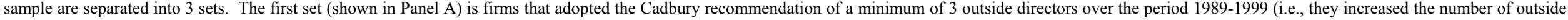

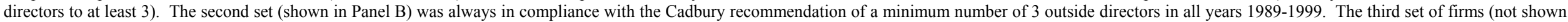
in the table) was never in compliance with the Cadbury recommendation of a minimum of 3 outside directors at anytime over the period 1989-1999. 
Table 4

Probit regressions of outside CEO appointments for a sample of 523 CEO appointments by 700 U.K. firms over the period 1989 through 1999

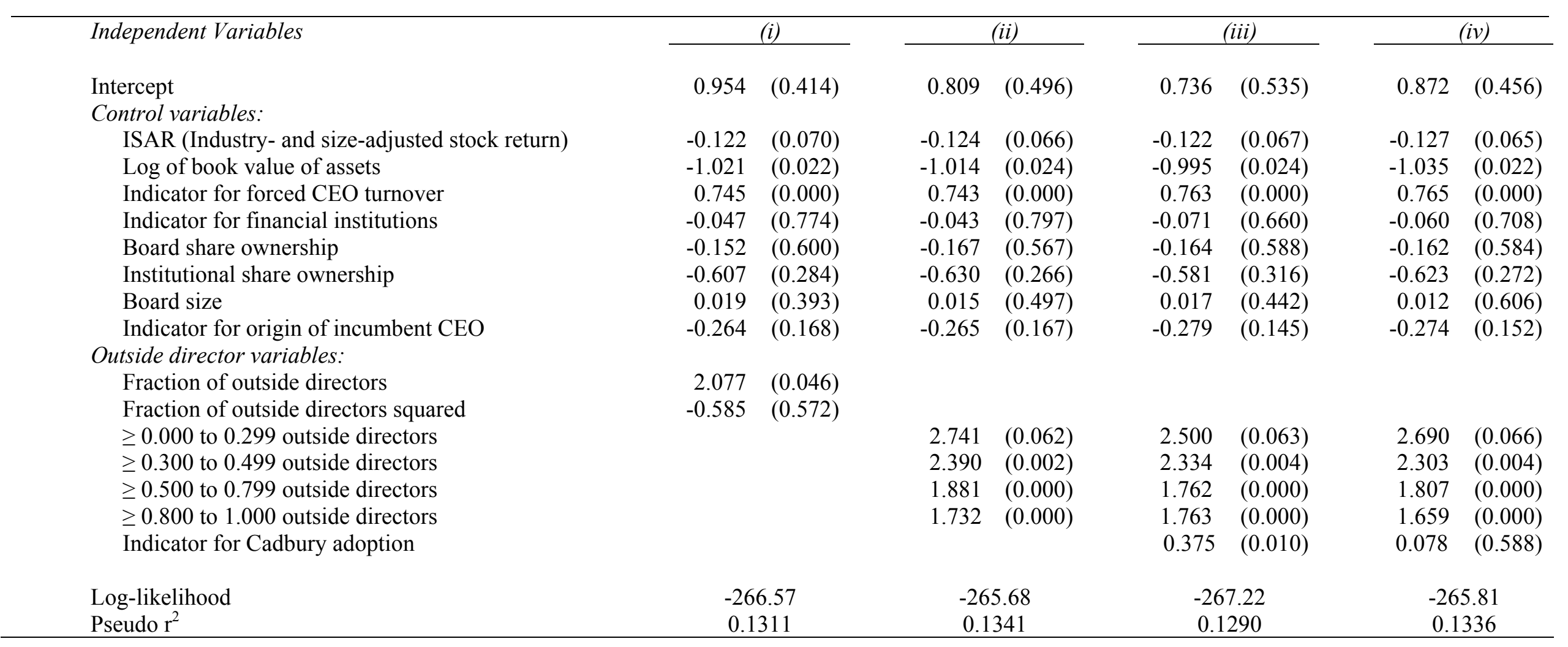

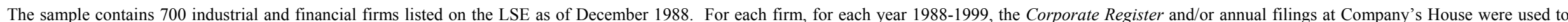

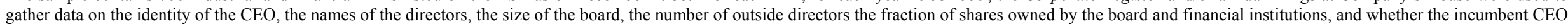

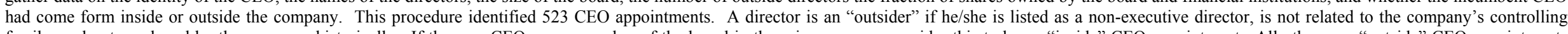

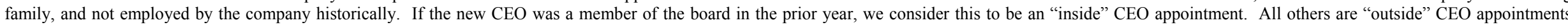

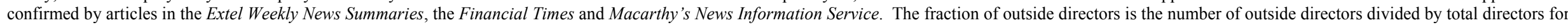

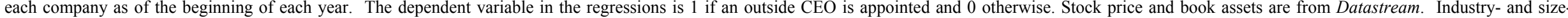

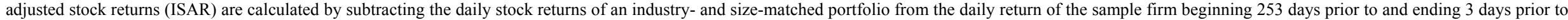

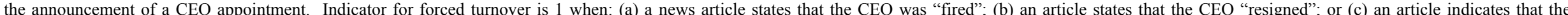

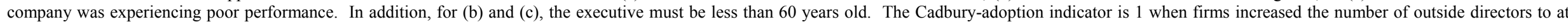
least three over the period 1993-1999. $p$-value for 2-tailed tests are in parentheses. 


\section{Table 5}

\section{Stock price response to 523 CEO appointments by 700 U.K. firms over the period 1989 through 1999}

Panel A : Stock price response on the announcement of CEO appointments

\begin{tabular}{|c|c|c|c|c|}
\hline & Number & $\begin{array}{l}\text { Inside CEO } \\
\text { appointments }\end{array}$ & Number & $\begin{array}{l}\text { Outside CEO } \\
\text { appointments }\end{array}$ \\
\hline Appointments & 367 & $0.203 \quad(0.20)$ & 156 & $0.794 \quad(0.01)$ \\
\hline Pre-Cadbury CEO appointments & 140 & $0.219 \quad(0.19)$ & 49 & $0.781 \quad(0.01)$ \\
\hline Post-Cadbury CEO appointments & 227 & $0.187 \quad(0.21)$ & 107 & $0.803 \quad(0.01)$ \\
\hline $\begin{array}{l}\text { Departing CEO had been appointed } \\
\text { from inside the firm }\end{array}$ & 319 & $0.210 \quad(0.19)$ & 127 & $0.818 \quad(0.01)$ \\
\hline $\begin{array}{l}\text { Departing CEO had been appointed } \\
\text { from outside the firm }\end{array}$ & 48 & $0.191 \quad(0.20)$ & 29 & $0.764 \quad(0.02)$ \\
\hline
\end{tabular}

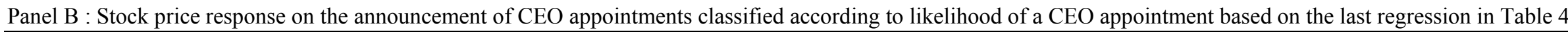
0.00 to 0.33 (Low probability)
49
$0.311(0.12)$
50
$1.135(<0.01)$
0.34 to 0.66 (Medium probability)
125
$0.207 \quad(0.20)$
57
$0.784(0.01)$
0.67 to 1.00 (High probability)
193
$0.097 \quad(0.62)$
49
$0.430 \quad(0.05)$

Panel C : Cross-sectional regressions for the 2-day announcement period excess return on the likelihood of a CEO appointment based on the last regression in Table 4
Regression coefficient (p-value)
367
$-0.168(0.29)$
156
$-0.435 \quad(0.10)$

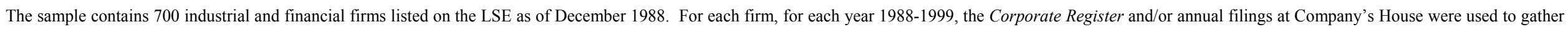

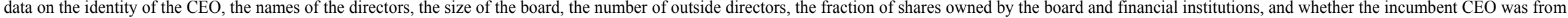

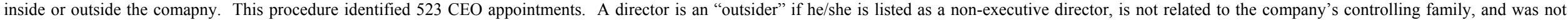

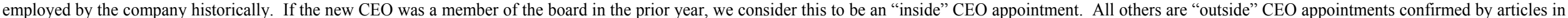

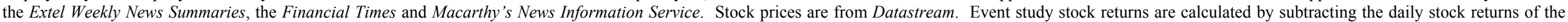

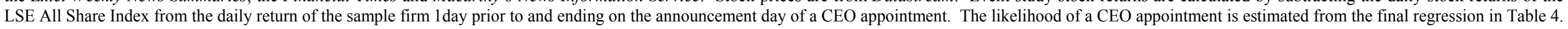
$p$-value for 2-tailed tests are in parentheses. 